\title{
Genetic and Cytogenetic Mapping of DMI1, DMI2, and DMI3 Genes of Medicago truncatula Involved in Nod Factor Transduction, Nodulation, and Mycorrhization
}

\author{
Jean-Michel Ané, ${ }^{1}$ Julien Lévy, ${ }^{1}$ Philippe Thoquet, ${ }^{1}$ Olga Kulikova, ${ }^{2}$ Françoise de Billy, ${ }^{1}$ Varma \\ Penmetsa, ${ }^{3}$ Dong-Jin Kim, ${ }^{3}$ Frédéric Debellé, ${ }^{1}$ Charles Rosenberg, ${ }^{1}$ Douglas R. Cook, ${ }^{3}$ Ton Bisseling, ${ }^{2}$ \\ Thierry Huguet, ${ }^{1}$ and Jean Dénarié ${ }^{1}$ \\ ${ }^{1}$ Laboratoire de Biologie Moléculaire des Relations Plante-Microorganismes, CNRS-INRA UMR215, BP27, 31326 \\ Castanet-Tolosan Cedex, France; ${ }^{2}$ Laboratory of Molecular Biology, Wageningen University, Dreijenlaan 3, 6703 HA \\ Wageningen, The Netherlands; ${ }^{3}$ Department of Plant Pathology, University of California, Davis CA95616, U.S.A.
}

Submitted 25 April 2002. Accepted 11 July 2002.

The DMI1, DMI2, and DMI3 genes of Medicago truncatula, which are required for both nodulation and mycorrhization, control early steps of Nod factor signal transduction. Here, we have used diverse approaches to pave the way for the map-based cloning of these genes. Molecular amplification fragment length polymorphism markers linked to the three genes were identified by bulked segregant analysis. Integration of these markers into the general genetic map of $M$. truncatula revealed that $D M I 1, D M I 2$, and $D M I 3$ are located on linkage groups 2,5 , and 8 , respectively. Cytogenetic studies using fluorescent in situ hybridization (FISH) on mitotic and pachytene chromosomes confirmed the location of DMI1, DMI2, and DMI3 on chromosomes 2,5 , and 8. FISH-pachytene studies revealed that the three genes are in euchromatic regions of the genome, with a ratio of genetic to cytogenetic distances between 0.8 and $1.6 \mathrm{cM}$ per $\mu \mathrm{m}$ in the DMI1, DMI2, and DMI3 regions. Through grafting experiments, we showed that the genetic control of the dmi1, dmi2, and dmi3 nodulation phenotypes is determined at the root level. This means that mutants can be transformed by Agrobacterium rhizogenes to accelerate the complementation step of map-based cloning projects for DMI1, DMI2, and DMI3.

The symbiosis between leguminous plants and rhizobial bacteria (e.g., Azorhizobium, Bradyrhizobium, Rhizobium, and Sinorhizobium species) results in the formation of a nitrogenfixing organ, the nodule. The initiation of nodule development is controlled by a signal exchange between the symbiotic partners. Legume roots secrete specific exudates, essentially flavonoids, that induce the transcription of rhizobial nodulation (nod, nol, and noe) genes that, in turn, specify the synthesis and secretion of lipo-chitooligosaccharidic nodulation signals, the Nod factors (Dénarié et al. 1996). Purified Nod factors trigger several responses in the roots of legume hosts similar to those induced by the bacteria themselves, such as root hair deformations, induction of nodulin genes and formation of nodule

J.-M. Ané, J. Lévy, and P. Thoquet contributed equally to this work.

Corresponding author: Jean Dénarié; E-mail: denarie@toulouse.inra.fr; Fax (33) 561285459. primordia (Long 1996; Schultze and Kondorosi 1998). Nod factors are active at very low concentrations $\left(10^{-9}\right.$ to $\left.10^{-12} \mathrm{M}\right)$ and their activity requires defined structural features, suggesting that the signals are recognized by specific receptors in the host plant. Because Nod factors trigger very diverse plant responses (e.g., cytoskeleton reorganization, gene expression, cell division, and induction of a developmental program) in different root tissues (epidermis, outer and inner cortex, and pericycle) and because these different responses can exhibit different Nod factor structural requirements, the Nod factor perception and transduction mechanisms are likely to be complex. Therefore, in addition to biochemical, pharmacological, and molecular approaches (Cullimore et al. 2001; den Hartog et al. 2001; Etzler et al. 1999; Gressent et al. 1999; Pingret et al. 1998), a genetic approach is also required to dissect these mechanisms.

For this genetic analysis of Nod factor perception and transduction, the model legume Medicago truncatula has been used. Following mutagenesis by ethyl methanesulphonate (EMS) or gamma ray irradiation, a screening for the isolation of mutants impaired for nodulation ( $\mathrm{Nod}^{-}$phenotype) was performed (Cook et al. 1999; Penmetsa and Cook 2000; Sagan et al. 1995). Among these $\mathrm{Nod}^{-}$mutants, those showing multiple defects in Nod factor responses, which are likely to be altered in Nod signal perception and transduction mechanisms, were found to belong to four complementation groups, corresponding to the DMI1, DMI2, DMI3, and NSP genes (Catoira et al. 2000). Interestingly, $d m i 1, d m i 2$, and $d m i 3$ mutants are also affected for mycorrhization ( $\mathrm{Nod}^{-} \mathrm{Myc}^{-}$mutants), suggesting that the transduction pathways of nodulation and mycorrhization signals share some common steps (Catoira et al. 2000). DMII and DMI2 genes are necessary for the induction of calcium spiking in root hairs, which is a very early response to Nod factors, and these genes probably act upstream of DMI3, which is not required for this response (Wais et al. 2000). It is now essential to clone these genes to get molecular clues about their functions in Nod factor signaling.

In this article, we use diverse approaches to pave the way for the positional cloning of $D M I$ genes. Using amplification fragment length polymorphism (AFLP) markers and bulked segregant analysis (BSA), we have shown that DMI1, DMI2, and $D M I 3$ are not clustered but are located on linkage groups 2, 5, and 8 , respectively. We also used fluorescent in situ hybridiza- 
tion (FISH) to confirm the genetic data and determine whether the three DMI genes are located in euchromatic or heterochromatic regions. Through grafting experiments, we showed that $d m i$ nodulation phenotypes are genetically controlled at the root level, which means that the Agrobacterium rhizogenes transformation method can be used for complementation experiments. These data should greatly facilitate the map-based cloning of the M. truncatula DMI genes.

\section{RESULTS}

\section{Mapping strategy.}

The dmil mutants (B129 and domi) were obtained after mutagenesis of the Jemalong A17 line, whereas the dmi2 (TR25) and dmi3 (TRV25) mutants were derived from the Jemalong J5 line (Table 1). Lines A17 and J5 as well as line J6, which was used for the construction of a $M$. truncatula genetic map, all derive by single-seed descent from the Jemalong commercial cultivar. No polymorphism could be detected between these lines, despite the use of more than 4,000 AFLP markers (Thoquet et al. 2002). These results indicate that the three lines can be considered as having an identical genotype, even if very limited differences in nucleotide sequence can not be excluded. These three lines will be referred to as Jemalong. In order to map these three $D M I$ genes, we have used the two existing genetic maps of $M$. truncatula. One is derived from a cross between Jemalong and the Algerian accession DZA315.16 (Thoquet et al. 2002) and the other from a cross between Jemalong and the Moroccan accession A20 (Penmetsa and Cook, 2000; D. J. Kim and D. Cook, personal communication).

First, we generated F2 populations between DZA315.16 and three Jemalong derivatives carrying the $d m i 1$, dmi2, and $d m i 3$ mutations. In all these F2 populations, we observed there were between 5.8 and $9.2 \%$ albino plants, which stopped growing after three days of culture. Since it was impossible to determine the nodulation phenotype of these albino plants, they were not taken into account for the segregation data. We looked for AFLP markers linked to the DMI genes, using the BSA method (Michelmore et al. 1991). Next, as previously described by Thoquet and associates (2002) with Jemalong $\times$ DZA315.16 crosses, about $30 \%$ of the AFLP bands showed polymorphism in the F2 progenies (Fig. 1A). Distances between the DMI genes and the linked markers were evaluated by genotyping the individuals of the F2 populations derived from crosses between mutants and DZA315.16. Subsequently, linked markers were mapped using the $\mathrm{F} 2$ population derived from the cross between the wild-type Jemalong line and DZA315.16 (Thoquet et al. 2002), allowing the localization of the mutations on the M. truncatula genome. The numbering and orientation of linkage groups and chromosomes is as proposed by Kulikova and associates (2001) and Thoquet and associates (2002).

\section{DMI1 is located on linkage group 2.}

For the DMI1 gene, $717 \mathrm{~F} 2$ individuals originating from a cross between the B129 mutant and DZA315.16 were tested for nodulation. We observed a slight segregation distortion of the $3: 1 \mathrm{Nod}^{+} / \mathrm{Nod}^{-}$ratio in this F2 population (Table 1 ). From this $\mathrm{F} 2$ population, $10 \mathrm{Nod}^{+}$and $10 \mathrm{Nod}^{-}$individuals were randomly chosen to constitute four DNA pools of five individuals each for the BSA. Screening these pools with 128 primer combinations allowed us to identify 13 AFLP markers linked to DMI1. All these markers were mapped on a F2 subpopulation composed of $74 \mathrm{Nod}^{+}$individuals and $134 \mathrm{Nod}^{-}$individuals which, being homozygous for the recessive $d m i 1$ mutation, are more informative to estimate the frequency of recombination events. This allowed us to build a local map of the DMII region (Fig. 1A). Some of these markers, PM01, PM02, PI09, PL06, PA01, and L131200 (Table 2), being already localized on the general M. truncatula map (Thoquet et al. 2002), we were able to map the DMII locus at the northern extremity of linkage group 2 (Fig. 2A). All the markers of this region available from both $M$. truncatula genetic maps were used to genotype the F2 individuals resulting from the cross between B129 and DZA315.16 (Figs. 1A and 2A). As CAPS (cleaved amplified polymorphic sequences) markers identified in a cross between Jemalong and line A20 did not show polymorphism between Jemalong and DZA315.16, they were converted to PCR-SSCP (polymerase chain reaction-single-strand conformation polymorphism) markers before mapping (Table 3). All these markers enabled a $19 \mathrm{cM}$ map of the DMII region to be constructed. Independent mapping experiments performed with a large F2 population consisting of $499 \mathrm{Nod}^{-}$individuals from a cross between domi, another dmil mutant of Jemalong, and the A20 line provided a more precise estimation of the genetic distances for some of these markers. In particular, CAPS marker DK407L, which appeared completely linked with the DMII locus in the B129 $\times$ DZA315.16 F2 population, was found to dissociate from $D M I 1$ in this large domi $\times$ A20 F2 population and was shown to be more centromeric than DMIl (data not shown).

\section{$D M I 2$ is located on linkage group 5.}

For DMI2, 665 F2 plants resulting from a cross between mutant TR25 and DZA315.16 were tested for nodulation. We observed a 3:1 $\mathrm{Nod}^{+} / \mathrm{Nod}^{-}$segregation ratio in this $\mathrm{F} 2$ progeny (Table 1). From this population, $10 \mathrm{Nod}^{-}$and $10 \mathrm{Nod}^{+}$individuals were randomly chosen to constitute DNA pools for BSA marker screening. The 63 primer combinations screened on the pools allowed us to find two AFLP markers tightly linked to DMI2 (PG03 and PJ06). Two SSR (simple sequence repeat) markers, JF20 and B42I11002 (Table 3), were also found to be linked to DMI2. For mapping purposes, a subpopulation of 117 $\mathrm{Nod}^{-}$and $282 \mathrm{Nod}^{+}$F2 individuals was used. The two AFLP markers were also mapped on the general F2 population (Thoquet et al. 2002) and appeared to be located near ENOD4O in the central region of linkage group 5 (Fig. 2B). In turn, ENOD40 was typed on the mapping population, as well as two CAPS markers (DK009-R and DK298-R) that are closely linked to ENOD40 on the M. truncatula map established between Jemalong and the A20 line. With these seven markers, we were able to construct a local map of the DMI2 region spanning $5 \mathrm{cM}$ (Fig. 1B).

Table 1. Genetic analysis of crosses between DMI mutants and the genotype DZA315.16

\begin{tabular}{|c|c|c|c|c|c|c|c|}
\hline \multirow[b]{2}{*}{ Mutants ${ }^{\mathrm{a}}$} & \multirow[b]{2}{*}{ Genes } & \multicolumn{2}{|c|}{ F1 } & \multicolumn{4}{|c|}{ F2 } \\
\hline & & Nod $^{+}$ & Nod $^{-}$ & Albino (\%) & Nod $^{+}$ & Nod $^{-}$ & $\chi^{2 b}$ \\
\hline B129 & $D M I 1$ & 10 & 0 & 9.2 & 583 & 134 & 3.88 \\
\hline TR25 & DMI2 & 6 & 0 & 5.8 & 494 & 171 & 0.18 \\
\hline TRV25 & $D M I 3$ & 4 & 0 & 6.1 & 227 & 81 & 0.28 \\
\hline
\end{tabular}

${ }^{a}$ Mutants were crossed to DZA315.16 Nod $^{+}$plants.

${ }^{\mathrm{b}} \chi^{2}$ calculated for a 3:1 ratio of $\mathrm{Nod}^{+} / \mathrm{Nod}^{-}$phenotype, $\mathrm{P}>0.05$ when $\chi^{2}<3.84$. Albino plants were not taken into account. 
DMI3 is located on linkage group 8.

For DMI3, 124 individuals from an F2 population between the TRV25 mutant and DZA315.16 were tested for nodulation. We observed a 3:1 $\mathrm{Nod}^{+} / \mathrm{Nod}^{-}$segregation ratio in this F2 population (Table 1). DNA samples from $10 \mathrm{Nod}^{+}$and $10 \mathrm{Nod}^{-}$ randomly chosen individuals were used to constitute the bulks and were amplified with 80 primer combinations, allowing the identification of 10 AFLP markers linked to DMI3 (Fig. 1C). The distance between these markers and the gene was first estimated on a mapping population composed of $81 \mathrm{Nod}^{-}$and 40 Nod $^{+}$F2 individuals. Four of these markers had already been located on the general map (PD24P, PB03, PE13, and PE14) (Thoquet et al. 2002) (Fig. 1C). Two other closely linked markers, PT01 and PU01, were also mapped on the general F2 mapping population between Jemalong and DZA315.16. Mapping data indicated that $D M I 3$ is located in the central region of linkage group 8 (Fig. 2C). Three SSR markers (MtBA05GO6, MtBA14A02, and MtBA08C08) were also found to be linked to the DMI3 locus. To have a more precise estimation of the distance between the closest markers and the DMI3 locus, three SSR markers and the AFLP marker PU01 were mapped on a population of $150 \mathrm{Nod}^{-}$individuals. These data allowed us to build a $23 \mathrm{cM}$ map around the DMI3 locus (Fig. 1C).

\section{Locating DMI genes on mitotic chromosomes by FISH.}

The development of fluorescent in situ hybridization (FISH) techniques facilitates the integration of cytogenetic and genetic maps (Harper and Cande 2000). Cytogenetic studies provide
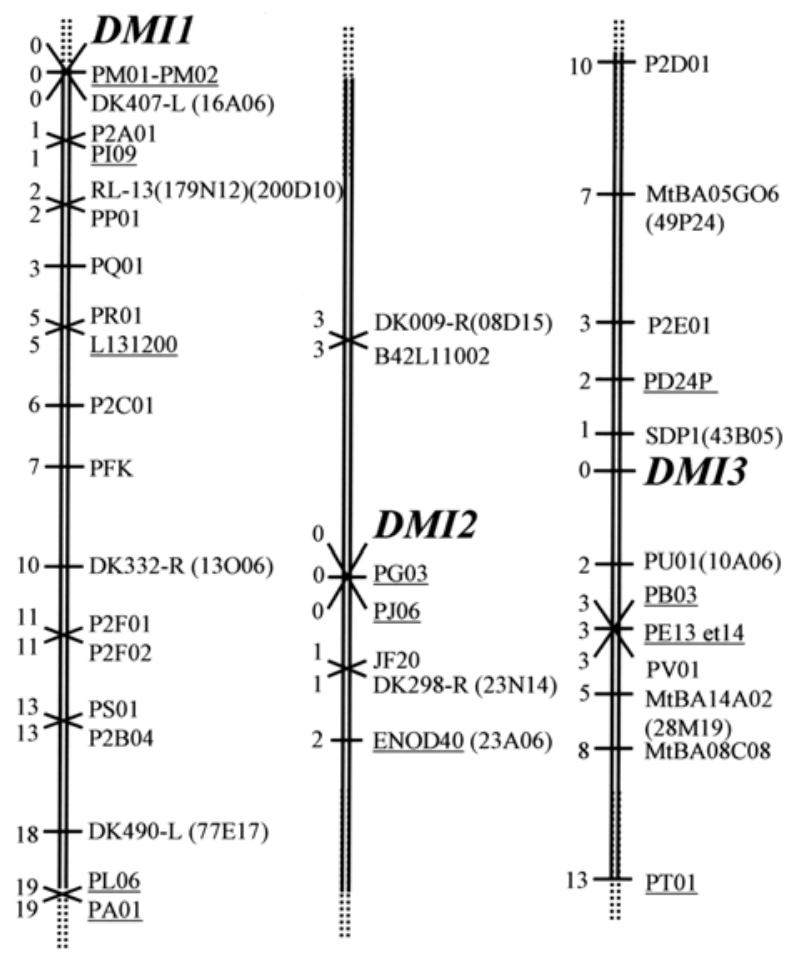

(A)

(B)

(C)

Fig. 1. Localization of amplification fragment length polymorphism, random amplified polymorphic DNA, and simple sequence repeat markers and corresponding BAC clones in the three DMI regions. The regions surrounding the three DMI loci are represented. The markers already mapped on the F2 population between Jemalong and DZA315.16, described in Thoquet et al. (2002) are underlined. The BAC clones used for the cytogenetic mapping are indicated in brackets close to the corresponding marker. A, linkage group $2 ; \mathbf{B}$, linkage group 5; $\mathbf{C}$, linkage group 8. unique information, such as centromere location, heterochromatin and euchromatin distribution, and in some conditions, the cytogenetic distances of loci, through the direct measurement of distances on chromosomes. DAPI (4',6-diamidino-2phenylindole) staining of chromosomes allows the distinction of euchromatic regions, which appear as weakly fluorescent, and heterochromatic regions, which correspond to a stronger fluorescent signal. Before initiating a program of positional cloning of a gene of interest, it is important to determine whether this gene is located in euchromatic or heterochromatic regions because, in heterochromatic regions, short genetic distances can represent large physical distances, due to low levels of meiotic recombination (Zhong et al. 1999).

These techniques have been successfully developed for $M$. truncatula (Cerbah et al. 1999; Kulikova et al. 2001), and a correspondence has been established between the eight genetic linkage groups and chromosomes of this species (Kulikova et al. 2001). In M. truncatula on metaphase or pachytene complements, heterochromatin is visible only in the nucleolar organizing region (NOR) corresponding to the $45 \mathrm{~S}$ rDNA region and in the pericentromeric regions.

To determine the cytogenetic location of the three DMI genes, FISH experiments were first carried out on prometaphase and metaphase chromosomes of the Jemalong line. For each DMI gene, the strategy was as follows. Markers around the gene were used to identify by hybridization corresponding BAC clones in the $M$. truncatula genome BAC library (Nam et al. 1999). These BAC probes were hybridized on mitotic chromosomes. To facilitate chromosome identification, these chromosomes were hybridized subsequently with BACs that had already been mapped on the different $M$. truncatula chromosomes (Kulikova et al. 2001). All our data on mitotic chromosomes correspond to at least ten observations.

The screening of the BAC genomic library with the DK490L and DK407L markers, which are located at $18 \mathrm{cM}$ and less than $0.5 \mathrm{cM}$ from the DMI1 gene, respectively, resulted in the identification of the BAC clones 77E17 and 16A06. These two BACs and the BAC $51 \mathrm{~J} 12$, which is known to be located on the long arm of chromosome 2 (Kulikova et al. 2001), were used as probes. BAC clones 77E17 and 16A06 gave hybridization signals on the same chromosome as BAC 51J12 but on the opposite arm. This result shows that DMII is located on the short arm of chromosome 2 (Fig. 3A and B). On prometaphase complements, which are slightly less condensed than metaphase chromosomes, the 16A06 BAC, which is tightly linked to the DMII locus, appeared to be very close to the telomeric region (Fig. 3C). All these observations are consistent with the genetic data.

To locate DMI2, BACs 8D15, 23A06, and 23N14 corresponding to markers mapped at 3,2 , and $1 \mathrm{cM}$, respectively, were used. The $45 \mathrm{~S}$ ribosomal DNA, which is located on the long arm of chromosome 5, was used as a control for chromosome identification (Kulikova et al. 2001). BAC clones 8D15 (Fig. 4A), 23N14 (Fig. 4B), and 23A06 (data not shown) were located on the other arm of chromosome 5 compared with the $45 \mathrm{~S}$ ribosomal DNA locus on metaphase complements. The DAPI staining suggested that these BACs were not located in the highly DAPI-stained pericentromeric region.

For DMI3, chromosome 8 was identified with BAC $41 \mathrm{H} 08$, which corresponds to the CAPS marker DK455L. The DNA fragment corresponding to the AFLP marker PU01 was cloned in the pGEM vector. Screening the BAC library using this AFLP cloned band allowed us to identify the 10A06 BAC clone. The SSR markers MtBA05GO6F1 and MtBA14A02, which mapped at $7 \mathrm{cM}$ and $5 \mathrm{cM}$, respectively, from the DMI3 locus, were used to identify the 49P24 and 28M19 BAC clones. Used as probes in FISH experiments, the 10A06, 49P24, and 28M19 BAC clones gave multiple hybridization 
spots flanking the centromeric regions of most of the chromosomes (Fig. 5A and B). Thus, the presence of repeated sequences in the three BACs used did not allow us to locate DMI3 by FISH experiments on metaphase chromosomes.

\section{Mapping DMI genes by FISH on pachytene chromosomes.}

FISH hybridization on pachytene chromosomes allows precise cytogenetic mapping of BACs with a resolution of about $60 \mathrm{~kb}$ (Kulikova et al. 2001), which makes possible the comparison of genetic $(\mathrm{cM})$ and cytogenetic $(\mu \mathrm{m})$ distances. DAPI staining of pachytene chromosomes allows identification of euchromatic and heterochromatic regions. In euchromatic regions, the determination of the $\mathrm{cM} / \mu \mathrm{m}$ ratio can lead to a preliminary estimation of the physical distance separating markers (or BACs), which is important information for initiating a chromosome walking approach. All cytogenetic distance estimations on pachytene complements correspond to at least eight measurements.

For DMI1, hybridizations on pachytene chromosomes from the Jemalong line showed that the gene is located at the extremity of the short arm of chromosome 2, in a euchromatic region (Fig. 3D, E, and F). We used BAC clones 16A06, $179 \mathrm{~N} 12,200 \mathrm{D} 10,13 \mathrm{O} 06$, and 77E17, which are located at approximately $0.5 \mathrm{cM}, 2 \mathrm{cM}, 2 \mathrm{cM}, 10 \mathrm{cM}$, and $18 \mathrm{cM}$ from the DMI1 gene, respectively, to estimate the cytogenetic distances between these markers. In this part of chromosome 2 , the average $\mathrm{cM} / \mu \mathrm{m}$ ratio was estimated to be 0.8 (Table 4 ). The $16 \mathrm{~A} 06$ BAC clone, which is the closest to DMI1, was located at about $2.3 \mu \mathrm{m}$ from the chromosome end. On $M$. truncatula Jemalong pachytene chromosomes, in a euchromatic region, $1 \mu \mathrm{m}$ has been reported to correspond to about $300 \mathrm{~kb}$ (Kulikova et al. 2001). Our measurements thus suggest that the DMII gene is located in a region comprised of $680 \pm 60 \mathrm{~kb}$ between the 16A06 BAC clone and the north telomere of chromosome 2.

For DMI2, the 23A06 BAC clone containing the ENOD40 gene has already been localized on the short north arm of chromosome 5 at about $40 \mu \mathrm{m}$ from the centromere (Kulikova et al. 2001). The DMI2 gene is closely linked to this marker $(2 \mathrm{cM})$ and so is located in the vicinity of the pericentromeric region but still within a euchromatic area in the Jemalong line. BAC clones $23 \mathrm{~N} 14$ and 8D15 correspond to genetic markers flanking the DMI2 locus and are separated by $4 \mathrm{cM}$. The average cytogenetic distance measured between these BACs by FISH

Table 2. Codes for amplification fragment length polymorphism markers on the F2 population between Jemalong and DZA315.16

\begin{tabular}{lcc}
\hline Code & EcoRI primer & Mse I primer \\
\hline $\mathrm{PA}$ & $E c o+\mathrm{AG}$ & $M s e+\mathrm{CAC}$ \\
$\mathrm{PB}$ & $E c o+\mathrm{AG}$ & $M s e+\mathrm{CAA}$ \\
$\mathrm{PD}$ & $E c o+\mathrm{AT}$ & $M s e+\mathrm{CAC}$ \\
$\mathrm{PE}$ & $E c o+\mathrm{AT}$ & $M s e+\mathrm{CAG}$ \\
$\mathrm{PI}$ & $E c o+\mathrm{AC}$ & $M s e+\mathrm{CAC}$ \\
$\mathrm{PG}$ & $E c o+\mathrm{AGA}$ & $M s e+\mathrm{CCA}$ \\
$\mathrm{PJ}$ & $E c o+\mathrm{AC}$ & $M s e+\mathrm{CTT}$ \\
$\mathrm{PL}$ & $E c o+\mathrm{AG}$ & $M s e+\mathrm{CTA}$ \\
$\mathrm{PM}$ & $E c o+\mathrm{AG}$ & $M s e+\mathrm{CGG}$ \\
$\mathrm{PP}$ & $E c o+\mathrm{AA}$ & $M s e+\mathrm{CGA}$ \\
$\mathrm{PQ}$ & $E c o+\mathrm{AA}$ & $M s e+\mathrm{CGC}$ \\
$\mathrm{PR}$ & $E c o+\mathrm{AC}$ & $M s e+\mathrm{CCG}$ \\
$\mathrm{PS}$ & $E c o+\mathrm{AC}$ & $M s e+\mathrm{CAG}$ \\
$\mathrm{PT}$ & $E c o+\mathrm{AC}$ & $M s e+\mathrm{CAA}$ \\
$\mathrm{PU}$ & $E c o+\mathrm{AG}$ & $M s e+\mathrm{CCG}$ \\
$\mathrm{PV}$ & $E c o+\mathrm{AT}$ & $M s e+\mathrm{CTG}$ \\
$\mathrm{P} 2 \mathrm{~A}$ & $E c o+\mathrm{TA}$ & $M s e+\mathrm{CTG}$ \\
$\mathrm{P} 2 \mathrm{~B}$ & $E c o+\mathrm{TA}$ & $M s e+\mathrm{CAT}$ \\
$\mathrm{P} 2 \mathrm{C}$ & $E c o+\mathrm{TA}$ & $M s e+\mathrm{CAG}$ \\
$\mathrm{P} 2 \mathrm{D}$ & $E c o+\mathrm{TC}$ & $M s e+\mathrm{CCC}$ \\
$\mathrm{P} 2 \mathrm{E}$ & $E c o+\mathrm{TC}$ & $M s e+\mathrm{CAT}$ \\
$\mathrm{P} 2 \mathrm{~F}$ & $E c o+\mathrm{TT}$ & $M s e+\mathrm{CGA}$ \\
\hline
\end{tabular}

on pachytene chromosomes was about $2.3 \mu \mathrm{m}$, suggesting an average ratio of $1.8 \mathrm{cM} / \mu \mathrm{m}$ in the $D M I 2$ region (Fig. $4 \mathrm{C}$ ).

For DMI3, BAC 43B05 was used to identify chromosome 8, on which this BAC clone had previously been shown to be located (O. Kulikova and D. J. Kim, unpublished data). BAC $28 \mathrm{M} 19$, which corresponds to a marker mapped at $5 \mathrm{cM}$ to the south of DMI3, showed a unique signal located on chromosome 8 (Fig. 5C). BAC 10A06, which could not be mapped on metaphase chromosomes and is likely to contain repeated sequences, showed multiple faint signals in the euchromatic regions surrounding the pericentromeric heterochromatin on most of the chromosomes and a strong signal on chromosome 8 between BACs 28M19 and 43B05. This order corresponds to the genetic map. Altogether, these results confirm that DMI3 and BACs 10A06 and 28M19 are closely linked on the south arm of chromosome 8 , as expected from the genetic data. The signal corresponding to the chromosome 8-specific probe 43B05 appears to be located at a short distance to the north of BAC 10A06. To determine the genetic distance between BAC 43B05 and the DMI3 locus, we analyzed a mapping population enlarged to $150 \mathrm{Nod}^{-}$individuals for the marker SDP1, which is a CAPS marker originating from the BAC 43B05. The SDP1 marker has been mapped at $1 \mathrm{cM}$ to the south of $D M I 3$, and the average $\mathrm{cM} / \mu \mathrm{m}$ ratio was estimated to be 1.6 (Table 4). These data indicate that the DMI3 gene is located in a euchromatic region flanked by the 43B05 and 10A06 BAC clones in the Jemalong line (Fig. 5C). According to the measurements performed on pachytene chromosomes from the Jemalong line, these markers are separated by approximately $600 \mathrm{~kb}$ (Table 4).

Since genetic mapping was performed using Jemalong-derived mutants and the DZA315.16 line, hybridizations were also performed on pachytene chromosomes of the DZA315.16 line, using the BACs 200D10, 23N14, and 43B05 as specific probes for the DMII, DMI2, and DMI3 loci, respectively (data not shown). The three $D M I$ genes appear to be also located in euchromatic regions in this line, indicating that recombination events should occur normally in the three DMI regions.

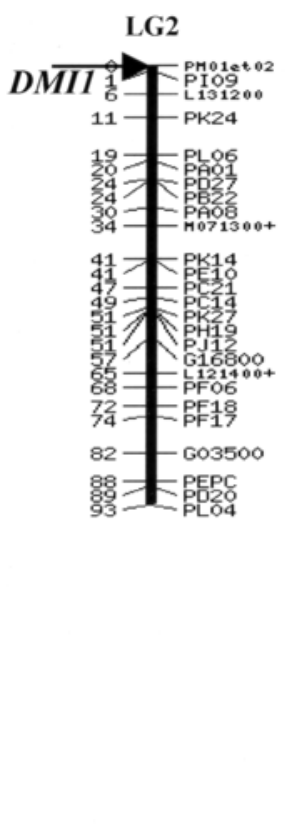

(A)
(B)

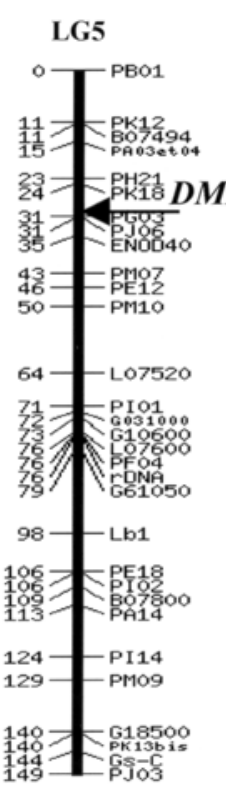

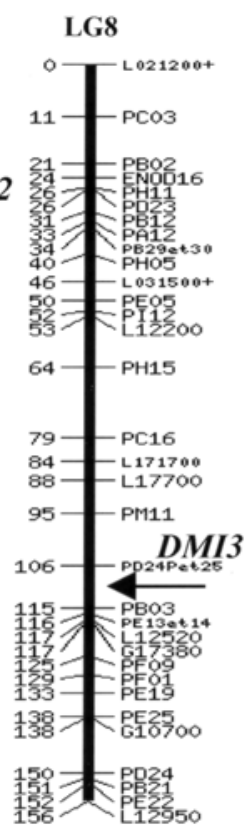

(C)
Fig. 2. Localization of the three $D M I$ loci on linkage groups 2,5 , and 8 . Linkage groups are as described in Thoquet et al. (2002). A, linkage group 2; $\mathbf{B}$, linkage group 5; $\mathbf{C}$, linkage group 8 . The position of the three $D M I$ loci on linkage groups 2,5 and 8 are indicated by arrows. 

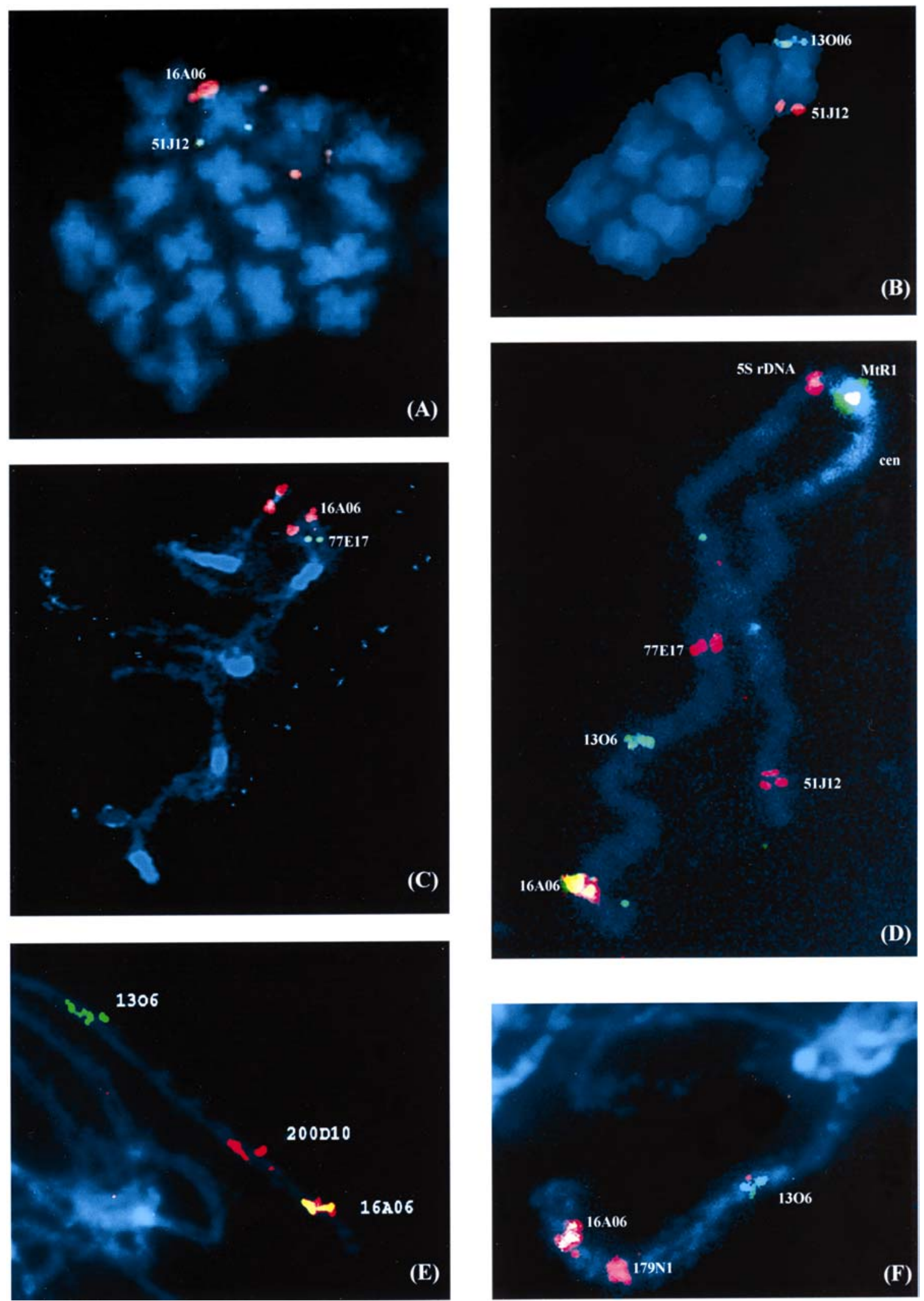

Fig. 3. Cytogenetic mapping of DMII by fluorescent in situ hybridization on metaphase, prometaphase, and pachytene chromosomes. Hybridization on A, metaphase chromosomes of BAC clones 16A06 (red) and B, $13 \mathrm{O} 06$ (green) from the DMI1 region. The 51J12 BAC clone is used as a reference probe for chromosome 2. The 16A06 and 13006 clones are both located at the extremity of the short arm of chromosome 2. C, Hybridization on prometaphase chromosomes of BAC 16A06 (red) and 77E17 (green). These two BAC clones, corresponding to markers tightly linked to the DMII locus, gave signals which could not be separated on metaphase chromosomes (data not shown). The observed signal order corresponds to the genetic data. D, E, and F, Hybridizations on pachytene chromosomes of BAC clones 16A06, 13O06, 77E17, 179N12, and 200D10 from the DMI1 region. Chromosome 2 is identified by the simultaneous presence of the 5S rDNA and MtR1 signals or by the use of the BAC 51J12 as a specific probe. cen = centromere position. The 16A06, 13O06, 77E17, 179N12, and 200D10 BAC clones are located on the short arm of chromosome 2 in a euchromatic region. The probe order corresponds to the genetic data. 
Root genotype determines $\mathrm{DMI}$ phenotype.

The final step for the positional cloning of the $D M I$ genes will involve a complementation test. This consists of transforming $d m i 1, d m i 2$, and $d m i 3 \mathrm{Nod}^{-}$mutants with DNA fragments carrying candidate genes, in order to restore the nodulation ability. A rapid system of genetic transformation of roots of $M$. truncatula has been developed using Agrobacterium rhizogenes (BoissonDernier et al. 2001). The transformed roots can be nodulated by Sinorhizobium meliloti, and the use of this system should greatly facilitate complementation assays. However, the use of $A$. rhizogenes implies that the trait under study is genetically controlled by the roots. Given that some altered nodulation phenotypes can be under the genetic control of the shoots (Postma et al. 1988), it was important to determine whether the DMI nodulation phenotypes are shoot- or root-controlled. To address this question, we performed graft experiments between Jemalong-derived mutants and wild-type Jemalong plants.

Shoots from mutant plants were grafted on roots of mutant plants and wild-type shoots on wild-type roots as negative and positive controls. Composite plants resulting from the graft of mutant shoots (B129, TR25, or TRV25) on wild-type roots were all able to nodulate. Reciprocally, roots of mutant plants grafted with the wild-type shoots developed no nodules 30 days after inoculation. We can conclude from this that, for $d m i 1, d m i 2$, and $d m i 3$ mutants, the nodulation phenotype is in each case genetically controlled at the root level. Therefore, it will be possible to perform complementation tests using the
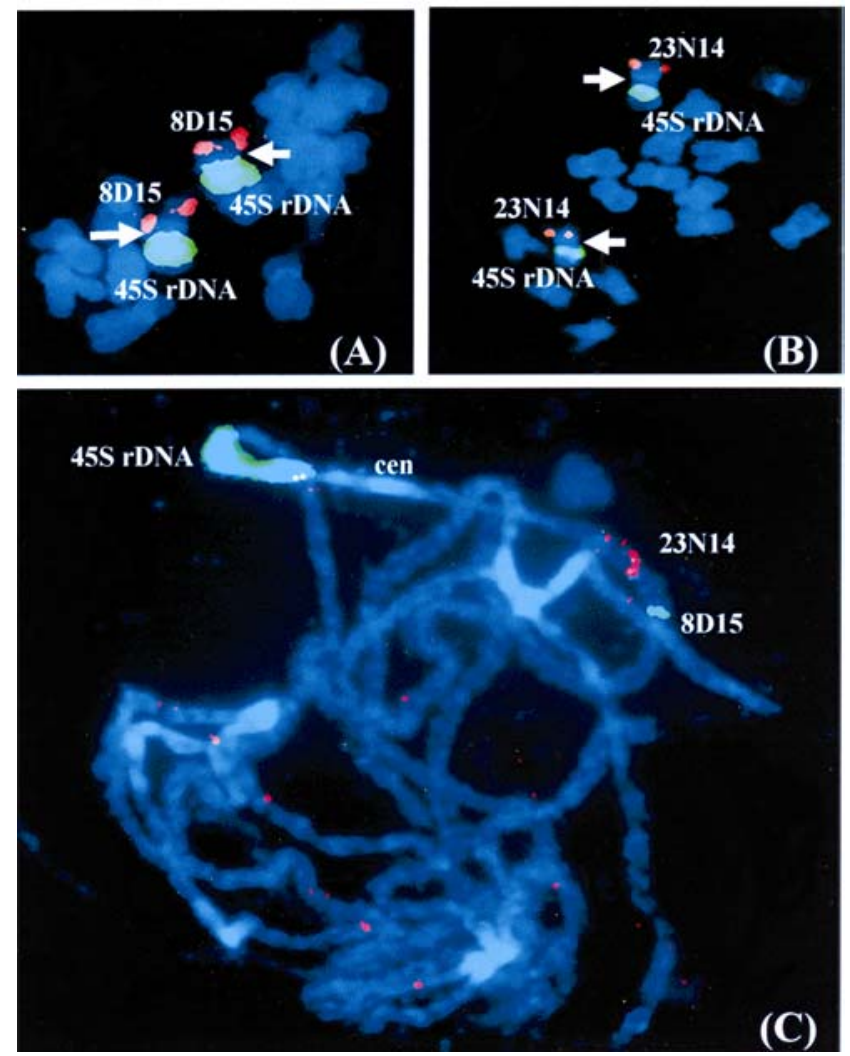

Fig. 4. Cytogenetic mapping of $D M I 2$ by fluorescent in situ hybridization on metaphase and pachytene chromosomes. Hybridization on metaphase chromosomes of $\mathbf{A}, \mathrm{BAC}$ clones 8D15 and $\mathbf{B}, 23 \mathrm{~N} 14$ flanking the DMI2 locus. The $45 \mathrm{~S}$ rDNA probe located on the long arm was used as a reference for chromosome 5 . White arrows indicate the centromere position. BAC clones $8 \mathrm{D} 15$ and $23 \mathrm{~N} 14$ are located on the short arm of chromosome 5. C, Hybridization on pachytene chromosomes of BAC clones 8D15 (green), 23N14 (red), and of the reference probe $45 \mathrm{~S}$ rDNA (green). BAC clones 8D15 and 23N14 are located on chromosome 5 in a euchromatic region. rapid transformation method by $A$. rhizogenes for the mapbased cloning of the three $D M I$ genes.

\section{DISCUSSION}

Mutants in the three $D M I$ genes exhibit very striking and similar phenotypes. They are defective for both nodulation and mycorrhization and are altered in numerous responses to Nod factors. Only one difference has been detected so far among $d m i$ mutants: in contrast to what is observed with a $d m i 3$ mutant, dmil and dmi2 mutants are defective for Nod factor-induced calcium spiking in root hairs (Wais et al. 2000). Allelism tests had previously placed the mutants in three complementation groups (Catoira et al. 2000). Genetic mapping presented here confirms that the DMI1, DMI2, and
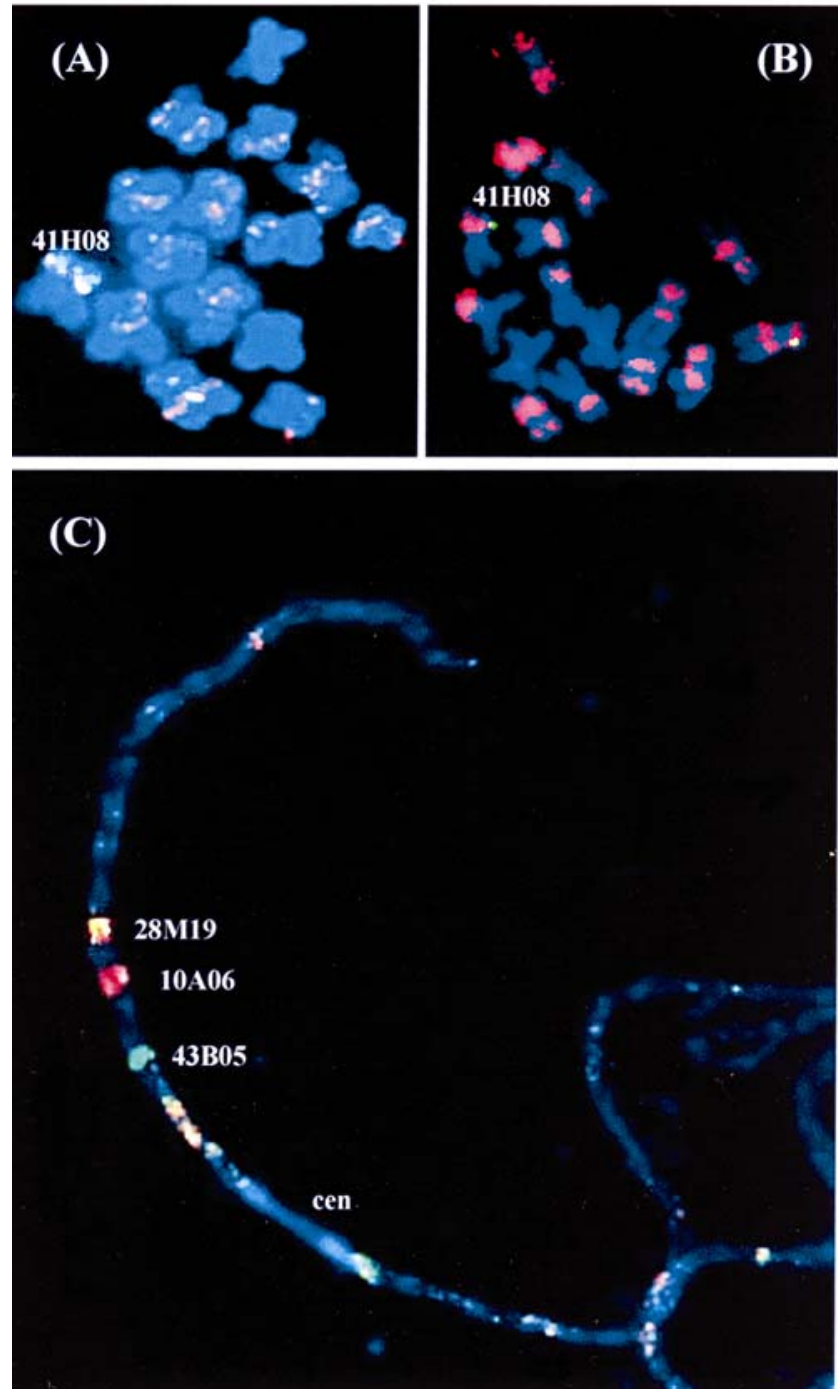

Fig. 5. Cytogenetic mapping of $D M I 3$ by fluorescent in situ hybridization on metaphase and pachytene chromosomes. A and B, The BAC 41H08 (green) is used as a specific probe for the identification of chromosome 8. The BAC 028M19 (red signals) gives a unique spot on metaphase chromosome 8 but also hybridizes to many other chromosomes. Hybridizations with probes consisting of the 010A06 and 049P24 BAC clones gave a similar pattern of signals (data not shown). C, Hybridization on pachytene chromosomes. The three BACs 43B05 (green), 028M19 (yellow), and 010A06 (red) are located on the same arm of chromosome 8 , in the order expected from the genetic data. According to the genetic data, the DMI3 locus is located between the BAC clones 43B05 and 010A06. The BAC clone 43B05 is used to identify chromosome 8. All three BAC clones are located in a euchromatic region on the short arm of chromosome 8 . 
DMI3 genes are independent genetic entities. Moreover, these three genes are not clustered and are located on linkage groups 2,5 , and 8 , respectively.

By performing FISH experiments on metaphase and pachytene chromosomes, we showed that these genetic locations are consistent with the cytogenetic mapping of the DMI genes on the corresponding chromosomes 2, 5, and 8. Furthermore, cytogenetic data indicate that DMII is located close to the telomeric region of the north arm of chromosome 2, and $D M I 2$ and DMI3 are close to the pericentromeric regions of chromosomes 5 and 8, respectively (Fig. 6). The F2 populations between TR25 (dmi2) or TRV25 (dmi3) and DZA315.16 show a $\mathrm{Nod}^{+} / \mathrm{Nod}^{-}$ratio of about 3:1, but this is not the case for the F2 population between B129 (dmil) and DZA315.16. This observation is consistent with the previously described distortion of the markers in the north region of linkage group 2 in the cross Jemalong $\times$ DZA315.16 (Thoquet et al. 2002).

The map-based cloning of genes located in heterochromatic parts of the genome is more difficult (Dean and Schmidt, 1995) because, in these regions, linkage distances are inaccurate due to low levels of meiotic recombination and the abundance of repetitive sequences can cause difficulties for BAC library screening and BAC contig construction. Thus, it was important to determine whether the DMI genes are located within heterochromatin regions or not. FISH on pachytene chromosomes from the Jemalong and the DZA315.16 lines showed that the three $D M I$ genes are located within euchromatic regions, which should facilitate their map-based cloning.

Hybridization with BAC clones from the DMI3 region on chromosome 8 showed that several of these clones contain repeated sequences. Signals were located mainly near the pericentromeric regions but also along chromosome arms. These multiple hybridizations resulted in the inability to locate $D M I 3$ by FISH on metaphase chromosomes. Hybridizations on pachytene chromosomes confirmed the multiple target sites of these BAC clones. Nevertheless, pachytene chromosomes being far more stretched than the metaphase complements, signals corresponding to the DMI3 region could be unambiguously identified in a euchromatin region of chromosome 8. These clones from the DMI3 region are the first $M$. truncatula BAC clones reported to show such hybridization patterns. Until now, the only pericentromeric repeat identified was MtRl (Kulikova et al. 2001). These BAC clones seem to contain repeated sequences that are present in the pericentromeric heterochromatic region and also repeated sequences that are present in the distal euchromatic regions. Sequencing of these BAC clones should provide information on the structure and distribution of these repeated sequences present in $M$. truncatula euchromatin.

For map-based cloning, it is important before making the decision to construct a BAC contig in the region of interest to estimate the physical distance between the closest markers flanking the target gene. The use of genetic distance alone can be misleading because the ratios between genetic distances and physical distances may vary with genome region (Dean and Schmidt 1995). DAPI stained pachytene chromosomes of $M$. truncatula are suitable to construct a detailed karyotype, and FISH hybridization allows mapping with a high resolution $(60 \mathrm{~kb})$ (Kulikova et al. 2001). The ratio of genetic to cytogenetic values was reported to range in $M$. truncatula Jemalong from 1 to $2 \mathrm{cM} / \mu \mathrm{m}$ for most marker pairs. We found that the ratio of genetic to cytogenetic values was around $1.5 \mathrm{cM} / \mu \mathrm{m}$ for markers linked to DMI2 and DMI3 genes that are located on chromosomes 5 and 8 , but was significantly lower (around $0.8 \mathrm{cM} / \mu \mathrm{m}$ ) for markers closely linked to $D M I I$ located near the extremity of chromosome 2. Presently, we do not know whether this difference reflects a difference of chromatin condensation or of recombination frequencies in this telomeric region.

A previous study found that the degree of chromatin condensation in a euchromatic part of chromosome 5 is about 300 $\mathrm{kb}$ per $\mu \mathrm{m}$ (Kulikova et al. 2001). However, it has been observed in Arabidopsis thaliana that the degree of condensation can vary among euchromatic regions of pachytene chromo-

Table 3. Genetic PCR-SSCP, CAPS, and SSR markers used in this study ${ }^{\mathrm{a}}$

\begin{tabular}{|c|c|c|c|c|c|}
\hline Marker name & Accession number & Marker type & Primer & Primer & Reference \\
\hline DK407-L & AQ917366 & CAPS AluI & $\begin{array}{l}\text { Left } \\
\text { Right }\end{array}$ & $\begin{array}{l}\text { TTAATTTTATCAACCCACCATATTAGTCAA } \\
\text { CCAGTGCTGGAAAAGACAATCAATC }\end{array}$ & This work \\
\hline RL-13 & $\ldots$ & CAPS MseI & $\begin{array}{l}\text { Left } \\
\text { Right }\end{array}$ & $\begin{array}{l}\text { GCCAAGCAGGTATCTATTCTTCATCT } \\
\text { CGGTACACAACATAACCCTAAAATCA }\end{array}$ & This work \\
\hline PFK & AA660630 & CAPS $S s p$ I & $\begin{array}{l}\text { Left } \\
\text { Right }\end{array}$ & $\begin{array}{l}\text { TCCCACTGCAAATCATGTCAAAAC } \\
\text { ACACAAGTGGATATTGATGGTTAGACTAC }\end{array}$ & This work \\
\hline DK332R & AQ917264 & PCR-SSCP & $\begin{array}{l}\text { Left } \\
\text { Right }\end{array}$ & $\begin{array}{l}\text { GGAAAATTATAAGCCAAACAACAGTAAAG } \\
\text { GATGATAACAATCGGGGAAAATAATG }\end{array}$ & This work \\
\hline DK490L & AQ917504 & CAPS & $\begin{array}{l}\text { Left } \\
\text { Right }\end{array}$ & $\begin{array}{l}\text { TGGTTCCAAATTCCACTCAAAAGC } \\
\text { AAAAATTGTGTTGTGGTTTAGTGGTAGAC }\end{array}$ & This work \\
\hline $\mathrm{JF} 20$ & AQ628987 & SSR [TTG]11 & $\begin{array}{l}\text { Left } \\
\text { Right }\end{array}$ & $\begin{array}{l}\text { ATAAACTCCCCGCAACCATC } \\
\text { GCCTGGTGGAACTGAACCTA }\end{array}$ & This work \\
\hline B42I11002 & AQ841515 & SSR [TC]11 & $\begin{array}{l}\text { Left } \\
\text { Right }\end{array}$ & $\begin{array}{l}\text { TCCATCACACCGTAACTTGC } \\
\text { TCGCTTGTATGCATCAGAAATCTT }\end{array}$ & This work \\
\hline ENOD40 & X80262 & CAPS AluI & $\begin{array}{l}\text { Left } \\
\text { Right }\end{array}$ & $\begin{array}{l}\text { TTAGTAGGATCTTCTCTTTCACTAGC } \\
\text { GCCTCCGATTATCAAAGGTCAAG }\end{array}$ & Crespi et al. 1994 \\
\hline DK009-R & AQ841079 & CAPS DraI & $\begin{array}{l}\text { Left } \\
\text { Right }\end{array}$ & $\begin{array}{l}\text { TAGCATCATCTTTCCCATACAA } \\
\text { GGGCAGGCAGCACCAGATA }\end{array}$ & This work \\
\hline DK298-R & AQ917141 & CAPS HaeIII & $\begin{array}{l}\text { Left } \\
\text { Right }\end{array}$ & $\begin{array}{l}\text { CCAACACATAGCCTTGATTC } \\
\text { GATAGAACTATTCATGAGCC }\end{array}$ & This work \\
\hline MtBA14A02 & AL367289 & SSR $[\mathrm{TC}] 9$ & $\begin{array}{l}\text { Right } \\
\text { Left }\end{array}$ & $\begin{array}{l}\text { TCTATGATGGATACGATACGG } \\
\text { AGATTTCAATTCTCAACAACC }\end{array}$ & This work \\
\hline MtBA08C08 & AL366491 & SSR $[A T] 31$ & $\begin{array}{l}\text { Right } \\
\text { Left }\end{array}$ & $\begin{array}{l}\text { TGACATGTATTGTTTATTTTCGTAACA } \\
\text { CCGTCCCTCCACGAAACT }\end{array}$ & This work \\
\hline MtBA05G06 & AL366233 & SSR [TC]11 & $\begin{array}{l}\text { Right } \\
\text { Left }\end{array}$ & $\begin{array}{l}\text { TAAATCCAGCTGCCCCAGTA } \\
\text { GGAGACTCACTCACACCCAAA }\end{array}$ & This work \\
\hline SDP1 & AI974323 & CAPS HinfI & $\begin{array}{l}\text { Right } \\
\text { Left }\end{array}$ & $\begin{array}{l}\text { TGGCTCTAAATCAGGGGAAGAATA } \\
\text { TGTGACGGTTGAATATCTGAATGTTT }\end{array}$ & This work \\
\hline
\end{tabular}

\footnotetext{
${ }^{\mathrm{a}} \mathrm{PCR}-\mathrm{SSCP}=$ polymerase chain reaction-single-strand conformation polymorphism, CAPS $=$ cleaved amplified polymorphic sequences, and SSR $=$ simple sequence repeats.
} 
somes. For example, it was found to range, from 250 to 540 $\mathrm{kb} / \mu \mathrm{m}$ on $A$. thaliana linkage group 4 (Fransz et al. 2000). If we hypothesize that the degree of chromatin condensation is similar in the three studied regions of $M$. truncatula, $1 \mu \mathrm{m}$ corresponding to about $300 \mathrm{~kb}$, our measurements would suggest that $1 \mathrm{cM}$ corresponds approximately to $200 \mathrm{~kb}$ in the $D M I 2$ and DMI3 regions and to more than $350 \mathrm{~kb}$ in the DMII region. Thus for the DMII region, $1 \mathrm{cM}$ would represent a physical distance much longer than in the DMI2 or DMI3 regions. When very close markers (distance of less than $400 \mathrm{~kb}$ ) are available, a more direct and precise estimation of physical distances in the regions of interest can be obtained from FISH experiments performed on extended DNA fibers (Fransz et al. 1996b; Jackson et al. 1998). This method should help to determine whether the variation of the ratio of genetic to cytogenetic values between chromosomes is due to differences in recombination frequencies or in chromosome compaction.

These mapping data open the way for a future search for correspondences between the three $M$. truncatula DMI genes and genes identified in other legumes that also control both nodulation and mycorrhization. MN-1008, a mutant deficient for nodulation, mycorrhization, and calcium spiking, has been identified in alfalfa (Medicago sativa) (Peterson and Barnes 1981). The corresponding locus, $n n 1$, is linked to ENOD40, U492, and U224 markers (Kiss et al. 2000). A strong conserved synteny between the $M$. sativa and the $M$. truncatula maps was observed in this region of chromosome 2 (Endre et al. 2002a; Thoquet et al. 2002). The NN1 gene of M. sativa and DMI2 of $M$. truncatula have been very recently cloned, indicating that they are orthologous genes. These genes code for a receptor kinase protein called NORK (Endre et al. 2002b) with an extracellular leucine rich repeat (LRR) domain. The function of this kinase receptor in Nod factor signaling still remains to be elucidated (Spaink et al. 2002).

Similarities have been observed in the genetic control of early steps of Nod factor transduction, nodulation, and mycorrhization in M. truncatula and Pisum sativum (pea) (Wais et al. 2000; Walker et al. 2000). Among the genes required for both nodulation and mycorrhization, two genes SYM 8 and SYM19 in pea and DMI1 and DMI2 in M. truncatula, are also required for calcium spiking, whereas one gene, SYM3O in pea and DMI3 in M. truncatula, are not required for calcium spiking and seem to act downstream of the other two. Though the pea haploid genome consists of seven chromosomes instead of
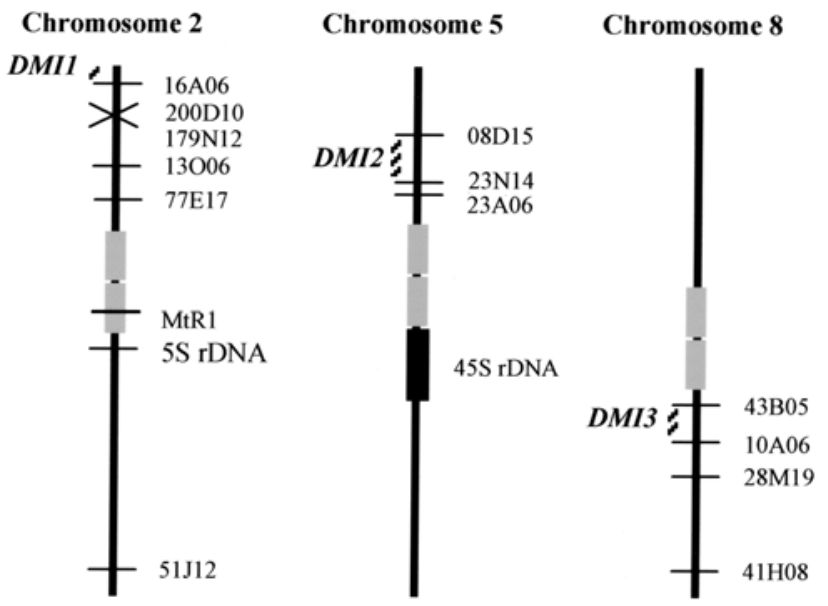

Fig. 6. Integrated genetic and cytogenetic map of the BAC clones linked to the three $D M I$ genes. The heterochromatic pericentromeric regions are indicated by gray boxes. The nucleolar organizing region corresponding to the $45 \mathrm{~S}$ rDNA probe is indicated by the black box. The regions containing the three $D M I$ loci are indicated by hatched bars. the eight for $M$. truncatula, a rather good conservation of synteny has been observed between the two species, and correspondences have been established between the linkage groups of the two species (Kalo et al. 2000). Interestingly, our mapping data suggest that the M. truncatula and pea genes controlling both nodulation and mycorrhization could be orthologues. In pea, the two genes controlling calcium spiking, SYM 8 and $S Y M 19$, have been mapped on linkage groups VI and I, which correspond respectively to linkage groups 2 and 5 of $M$. truncatula (Kalo et al. 2000). Moreover, SYM19 is linked to ENOD40, as is DMI2 in M. truncatula SYM30, which is not involved in calcium spiking, is located on linkage group IV, which corresponds to linkage group 8 of $M$. truncatula (Schneider et al 2002). These data suggest that SYM8 could correspond to DMI1, SYM19 to DMI2, and SYM2 to DMI3. The recent cloning of DMI2 and NN1 genes in M. truncatula and $M$. sativa, respectively, confirmed that these genes are real orthologues of the SYM19 gene from pea (Endre et al. 2002b). Moreover, the corresponding gene from Lotus japonicus has also been isolated (Stracke et al. 2002). The cloning of the DMII and DMI3 genes in M. truncatula would thus facilitate the subsequent cloning of orthologues in other phylogenetically closely related species such as pea.

The use of A. rhizogenes instead of A. tumefaciens for complementation tests should considerably facilitate a map-based cloning approach, since three weeks are sufficient for the formation of nodulated transgenic roots, while the regeneration of transgenic plants transformed by A. tumefaciens takes several months (Boisson-Dernier et al. 2001). The choice of $A$. rhizogenes, however, implies that the gene responsible for the phenotype of interest is expressed at the root level. The fact that a phenotype is visible at the root level does not necessarily mean that the corresponding genes act root autonomously. For instance, in pea, grafting experiments have shown that the phenotype of supernodulating mutants is determined by the aerial part of the plant (Postma et al. 1988). Furthermore, earlier work on the sym19 mutant K24 of pea indicated that the altered nodulation phenotype is dependant on the root. Nevertheless, the mutant shoot was able to diminish the nodule number on a wild-type stock (Postma et al. 1988; Weeden et al. 1990). For mutants in the three DMI genes, our grafting experiments clearly showed that the phenotype is only controlled in each case by the roots. No diminution of the nodule number was observed when a mutant shoot was grafted on a wild-type stock. For the three DMI genes of M. truncatula, the root control of the mutant phenotypes shows that it should be possible to use A. rhizogenes transformation to speed up the complementation step for a map-based cloning approach.

\section{MATERIALS AND METHODS}

\section{Plant material and DNA extraction.}

M. truncatula lines Jemalong, A20, and DZA315.16 are wild-type plants, $\mathrm{Nod}^{+} \mathrm{Fix}^{+}$with $\mathrm{S}$. meliloti (Penmetsa and Cook 1997, 2000; Sagan et al. 1995; Thoquet et al. 2002). Domi and B129 are EMS mutants of Jemalong altered in DMII (Catoira et al. 2000; Penmetsa and Cook 1997). TR25 and TRV25 mutants are $\gamma$-ray mutants of Jemalong altered in DMI2 and in DMI3, respectively (Sagan et al. 1995, 1998). Seeds were sterilized and germinated as described by Catoira and associates (2000). Plants were axenically grown on Fahraeus agar (1.5\%), either as slopes for nodulation tests (Truchet et al. $1985)$ or in petri dishes after grafting. Plants were also grown in liquid media, either in aeroponic culture for the production of large F2 populations and nodulation tests (Catoira et al. 2000) or in growth pouches for grafting (Journet et al. 1994). For nodulation tests, we used Sinorhizobium meliloti 2011 
(pXLGD4) (= GMI6526) (Ardourel et al. 1994). Plants were inoculated with a $0.5 \mathrm{ml}$ suspension of $10^{8}$ bacteria per $\mathrm{ml}$ in water all over the root system two days after germination for nodulation tests in tubes and with $20 \mathrm{ml}$ of the bacterial suspension after five days in aeroponic culture. Mutants were manually crossed (Thoquet et al. 2002) with the $\mathrm{Nod}^{+} M$. truncatula Algerian line DZA315.16. In these crosses, $M$. truncatula DZA315.16 was used as the source of pollen, which was transferred to flowers of emasculated mutant plants. F2 plants were grown either on agar slopes or in aeroponic cultures. DNA was extracted from leaf tissue of 3-week-old seedlings and was dried overnight at $65^{\circ} \mathrm{C}$, according to the protocol described by Ghérardi and associates (1998).

\section{Grafting experiments.}

We used the following protocol provided by E. P. Journet for reciprocal grafting between plantlets of $M$. truncatula. Grafting was carried out between scions and roots from 4-day-old plants (approximately $8 \mathrm{~cm}$ long) in a sterile environment. Seedlings were cut at the hypocotyl, using a razor blade. Shoots and roots were assembled and inserted into a capillary tube (internal diameter $0.9 \mathrm{~mm}$ ). The root and shoot junctions produced axillary roots that were regularly cut to allow the development of grafted roots. Grafted plants were grown in petri dishes on agar Fahraeus medium in a controlled growth chamber and were inoculated with S. meliloti 2011 (pXLGD4) 7 days after grafting. Growth of the rootstock resumed after a lag period of 5 to 14 days. The nodulation phenotype was assessed 30 days after inoculation.

\section{AFLP technique.}

AFLP analysis was performed according to Vos and associates (1995) as modified by Moreau and associates (1998). We used the 'tetracutter' restriction enzyme MseI and the 'hexacut- ter' EcoRI. AFLP reactions were carried out using a primer specific to the EcoRI adapter containing two selective nucleotides $(E c o+2)$ and a primer to the $M s e I$ adapter containing three selective nuclevotides $(M s e+3)$. Two different $E c o+2$ and 16 different $\mathrm{Mse}+3$ primers were used. The names of previously mapped markers were kept (Thoquet et al. 2002), and the names of new ones are indicated in Table 2. Polymorphic bands were identified by the code of the Eco or Mse combination followed by a number corresponding to the band number in the parental profile. We considered AFLP markers as discrete characters on a presence or absence alternative, and the intensity of bands was not taken into account.

\section{Cloning of DNA fragments corresponding to AFLP markers.}

The AFLP band was eluted from the gel and was cloned in the pGEM-T vector as described in Meksem and associates (2001). To identify the cloned fragment corresponding to the AFLP band, primers specific to the EcoRI adapter containing 8 selective nucleotides (E+8) were designed. One E+8 primer was designed for each cloned fragment. Polymorphism was identified using the standard AFLP procedure. For fragments showing polymorphism between the mapping parents, segregation analysis on a population of $11 \mathrm{Nod}^{-}$individuals allowed the cloned fragment corresponding to the AFLP polymorphic band to be identified. The Eco+8 (E+AGGCTGTA) and the $\mathrm{Mse}+3$ (M+CCG) primers allowing the amplification of this polymorphic band were then used on $150 \mathrm{Nod}^{-}$individuals for genetic mapping.

\section{BSA analysis.}

Our strategy used BSA to find markers linked to the DMI genes (Michelmore et al. 1991). We compared AFLP patterns of segregant pools from the F2 populations between the mu-

Table 4. Comparison of genetic and cytogenetic distances in the neighboring regions of $D M I$ genes

\begin{tabular}{|c|c|c|c|c|}
\hline Region & BAC clones & Genetic distance (cM) & Cytogenetic distance $(\mu \mathrm{m})$ & Average $\mathrm{cM} / \mu \mathrm{m}$ ratio \\
\hline DMII & Telomere-16A06 & / & $2.27 \pm 0.19$ & l \\
\hline DMII & 16A06-179N12 & 2 & $2.36 \pm 0.15$ & 0.8 \\
\hline DMII & $179 \mathrm{~N} 12-13 \mathrm{O} 06$ & 8 & $5.72 \pm 0.18$ & 1.4 \\
\hline DMII & 16A06-13A06 & 10 & $7.78 \pm 0.21$ & 1.3 \\
\hline DMI1 & 13A06-77E17 & 8 & $5.26 \pm 0.24$ & 1.5 \\
\hline DMI2 & 23N14-8D15 & 4 & $2.26 \pm 0.53$ & 1.8 \\
\hline$D M I 3$ & 43B05-10A06 & 3 & $1.87 \pm 0.70$ & 1.6 \\
\hline DMI3 & 43B05-28M19 & 6 & $4.07 \pm 0.27$ & 1.5 \\
\hline
\end{tabular}

Table 5. BAC clones and corresponding genetic markers used in this study

\begin{tabular}{|c|c|c|c|c|c|}
\hline BAC clone abbreviated name & BAC clone ID & Genetic marker & Linkage group & BAC end ${ }^{a}$ & Accession number \\
\hline 16A06 & Mt_H1T07_016A06 & DK407-L & LG2 & $\begin{array}{l}\text { T7 } \\
\text { SP6 }\end{array}$ & $\begin{array}{l}\text { BH001422 } \\
\text { BH001421 }\end{array}$ \\
\hline $179 \mathrm{~N} 12$ & Mt_H2D04_179N12 & RL-13 & LG2 & $\ldots$ & $\ldots$ \\
\hline 200D10 & Mt_H2D04_200D10 & RL-13 & LG2 & $\ldots$ & $\ldots$ \\
\hline 1306 & Mt_H1T07_013006 & DK332-R & LG2 & $\begin{array}{l}\text { T7 } \\
\text { SP6 }\end{array}$ & $\begin{array}{l}\text { AQ917263 } \\
\text { AQ917264 }\end{array}$ \\
\hline 77E17 & Mt_H1T07_077E17 & DK490-L & LG2 & $\begin{array}{l}\text { T7 } \\
\text { SP6 }\end{array}$ & $\begin{array}{l}\text { AQ917504 } \\
\text { AQ917505 }\end{array}$ \\
\hline $8 \mathrm{D} 15$ & Mt_H1T07_008D15 & DK009-R & LG5 & $\begin{array}{l}\text { T7 } \\
\text { SP6 }\end{array}$ & $\begin{array}{l}\text { AQ841078 } \\
\text { AQ841079 }\end{array}$ \\
\hline $23 \mathrm{~N} 14$ & Mt_H1T07_023N14 & DK298-R & LG5 & $\begin{array}{l}\text { T7 } \\
\text { SP6 }\end{array}$ & $\begin{array}{l}\text { AQ917140 } \\
\text { AQ917141 }\end{array}$ \\
\hline $23 \mathrm{~A} 06$ & Mt_H1T07_023A06 & ENOD40 & LG5 & $\ldots$ & $\ldots$ \\
\hline $28 \mathrm{M} 19$ & Mt_H2D04_028M19 & MtBA14A02 & LG8 & $\ldots$ & $\ldots$ \\
\hline $49 \mathrm{P} 24$ & Mt_H2D04_049P24 & MtBA05G06 & LG8 & $\ldots$ & $\ldots$ \\
\hline $10 \mathrm{~A} 06$ & Mt_H2D04_010A06 & JL1 & LG8 & $\ldots$ & $\ldots$ \\
\hline $43 \mathrm{H} 08$ & Mt_H1T07_43H08 & DK455L & LG8 & $\begin{array}{l}\text { T7 } \\
\text { SP6 }\end{array}$ & $\begin{array}{l}\text { AQ917442 } \\
\text { AQ917443 }\end{array}$ \\
\hline 43B05 & Mt_H1T07_043B05 & SDP1 & LG8 & $\ldots$ & $\ldots$ \\
\hline
\end{tabular}

a The T7 and SP6 promoters are present on both sides of the HindIII cloning site in the pBeloBAC11 vector and are used to give an orientation of the insert. 
tants (B129, TR25, and TRV25) and DZA315.16. We first randomly selected $10 \mathrm{Nod}^{-}$(homozygous plants) and $10 \mathrm{Nod}^{+}$(homozygous and heterozygous plants) F2 individuals to prepare two $\mathrm{Nod}^{+}$and two $\mathrm{Nod}^{-}$bulks of five individuals each. Since the $\mathrm{Nod}^{+}$pools contained heterozygous plants, only markers corresponding to a band amplified by PCR in DZA315.16 could be identified.

\section{SSR and PCR markers.}

All the PCR-derived markers were amplified with a PCR cycle of $94^{\circ} \mathrm{C}$ for $4 \mathrm{~min}$, followed by 40 cycles at $94^{\circ} \mathrm{C}$ for $30 \mathrm{~s}$, $55^{\circ} \mathrm{C}$ for $30 \mathrm{~s}$, and $72^{\circ} \mathrm{C}$ for $1 \mathrm{~min}$, followed by $4 \mathrm{~min}$ at $72^{\circ} \mathrm{C}$. Reactions were performed using $10 \mathrm{ng}$ of genomic DNA, 1.5 $\mathrm{mM} \mathrm{MgCl} 2,200 \mu \mathrm{M}$ of each dNTP, $1 \mathrm{U}$ of Taq polymerase, and 5 pmol of each primer (Table 3 ).

The SSR were screened on a $3.5 \%$ agar gel $(0.5 \times$ Tris-borate buffer (pH 8.3), 2 mM EDTA) after ethidium bromide staining. For the ENOD4O gene, the PCR products were digested before loading with $5 \mathrm{U}$ of $A l u \mathrm{I}$, the DK009-R with $5 \mathrm{U}$ of $\mathrm{DraI}$, and DK298-R with $5 \mathrm{U}$ of HaeIII as described by the supplier (Gibco BRL, Bethesda, MD, U.S.A.). All of these were scored as codominant markers.

\section{PCR-SSCP analysis.}

Fragments of about $300 \mathrm{bp}$ were amplified using specific primers (Table 3). For SSCP analysis, $7 \mu \mathrm{l}$ of PCR products were added to the same volume of a solution containing $95 \%$ formamide, $20 \mathrm{mM}$ EDTA, $0.05 \%$ bromophenol blue, and $0.05 \%$ xylene cyanol. Products were denaturated at $95^{\circ} \mathrm{C}$ for 4 min and were kept on ice until loaded onto a $9 \%$ polyacrylamide gel containing $0.5 \times$ Tris-borate buffer $(\mathrm{pH} 8.3), 2 \mathrm{mM}$ EDTA, and $10 \%$ glycerol. Electrophoresis was performed at $300 \mathrm{~V}$ for $15 \mathrm{~h}$ at $4^{\circ} \mathrm{C}$. The gel was stained by a standard silver-staining method and then dried on filter paper on a vacuum slab dryer.

\section{Genetic maps construction.}

The genetic maps were constructed using the MapMaker/Exp v. 3.0 software (Lander et al. 1987). Distances were expressed in Kosambi centiMorgans. Segregation data were tested for deviation from the expected Mendelian ratio using a Chi-square test.

\section{Genomic DNA libraries.}

All the M. truncatula BAC libraries used in this study have been constructed with the Jemalong line. Most BAC clones came from the BAC library described by Nam and associates (1999) and are designated by the Mt_H1T07_ prefix followed by five characters indicating the position in the library plates (plate, line, column) as previously described. In this study, we used the abbreviated names presented in Table 5. For five clones, we used a different BAC library. This new BAC library is highly similar to the previous one (vector, cloning site), except that it represents 23-genome equivalents and that the average insert size is larger (about $120 \mathrm{~kb}$ ) (D. R. Cook, unpublished data). The clones from this library are identified by the Mt_H2D04_ prefix followed by the position in the library plates (plate, line, column). The abbreviated names are indicated in Table 5.

The BAC library screening was performed as described by Nam and associates (1999) by filter hybridization. BAC plasmid DNA was isolated using an alkaline lysis procedure. When the genetic marker was used as a probe to screen the library, the different BAC clones were analyzed by the classical fingerprinting procedure using the HindIII and EcoRI enzymes. The different clones were also used for Southern blot hybridizations and PCR experiments to check their overlapping. For each genetic marker, just one clone from these overlapping BACs was arbitrarily chosen for further experiments. All standard DNA manipulations were performed as described elsewhere (Sambrook et al. 1989).

\section{FISH.}

For the preparation of mitotic metaphase chromosomes, we used root meristems from young seedlings. M. truncatula plants were grown between two humid filter papers laying on Fahraeus agar $(1.5 \%)$ medium. This procedure increased the number of metaphase spreads up to 10-fold in comparison with other growing procedures. The preparation of mitotic chromosomes was performed as previously described (Cerbah et al. 1999). The preparation of meiotic pachytene chromosomes was performed as described by Kulikova and associates (2001). The labeling of probes was performed with biotin-16-dUTP or digoxigenin-11-dUTP using the nick translation mix (Boehringer, Mannheim, Germany). Probes were precipitated by standard ethanol procedure and stored at $-20^{\circ} \mathrm{C}$.

FISH was performed as described by Zhong and associates (1996) with the following modifications. No pepsin treatment was used for pachytene chromosomes and, for metaphase chromosomes, the pepsin treatment was replaced with a 10-min treatment with proteinase $\mathrm{K}(100 \mathrm{ng} / \mathrm{ml})$ at $37^{\circ} \mathrm{C}$. Double fluorescence detection was performed according to Fransz and associates (1996a). Chromosomes were counter-stained with DAPI (4',6-diamidino-2-phenylindole) in Vectashield antifade solution (Vector Laboratories Inc., Burlingame, CA, U.S.A.), 1 $\mu \mathrm{g} / \mathrm{ml}$. Pachytene chromosomes were studied and photographed as described by Kulikova and associates (2001). The results described correspond to at least 10 observations. Measurements were performed using the free software program from Colorado State University.

\section{ACKNOWLEDGMENTS}

We are grateful to E. P. Journet for providing a protocol for grafting $M$. truncatula seedlings and data from grafting experiments between the TR25 mutant and Jemalong and F1 seeds from a cross between TRV25 and DZA315.16. We thank C. Gough for critically reading the manuscript and G. Blazy for her skillful technical assistance. J. M. Ané and J. Lévy were funded by the French Ministère de l'Enseignement Supérieur et de la Recherche. This work was supported by the Human Frontier Science Program Organization (Grant Number RG0327/1998-M), the European Union (Contract MEDICAGO QLG2-CT-2000-00676) and the Institut National de la Recherche Agronomique (ATS 2000-P00241).

\section{LITERATURE CITED}

Ardourel, M., Demont, N., Debellé, F., Maillet, F., De Billy, F., Promé, J. C., Dénarié, J., and Truchet, G. 1994. Rhizobium meliloti lipooligosaccharide nodulation factors: Different structural requirements for bacterial entry into target root hair cells and induction of plant symbiotic developmental responses. Plant Cell. 6:1357-1374.

Boisson-Dernier, A., Chabaud, M., Garcia, F., Bécard, G., Rosenberg, C., and Barker, D. G. 2001. Agrobacterium rhizogenes-transformed roots of Medicago truncatula for the study of nitrogen-fixing and endomycorrhizal symbiotic associations. Mol. Plant-Microbe Interact. 14:695700 .

Catoira, R., Galera, C., De Billy, F., Penmetsa, R. V., Journet, E. P., Maillet, F., Rosenberg, C., Cook, D., Gough, C., and Dénarié, J. 2000. Four genes of Medicago truncatula controlling components of a Nod factor transduction pathway. Plant Cell. 12:1647-1666.

Cerbah, M., Kevei, Z., Siljak-Yakolev, S., Kondorosi, E., Kondorosi, A., and Trinh, T. H. 1999. FISH chromosome mapping allowing karyotype analysis in Medicago truncatula lines Jemalong J5 and R-108-1. Mol. Plant-Microbe Interact. 12:947-950.

Cook, D. R. 1999. Medicago truncatula: A model in the making! Curr. Opin. Plant Biol. 2:301-304.

Crespi, M. D., Jurkevitch, E., Poiret, M., Daubenton-Carafa, Y., Petrovics, G., Kondorosi, E., and Kondorosi, A. 1994. ENOD40, a gene expressed during nodule organogenesis, codes for a non-translatable RNA involved in plant growth. EMBO (Eur. Mol. Biol. Organ.) J. 13:5099-5112. 
Cullimore, J. V., Ranjeva, R., and Bono, J. J. 2001. Perception of lipochitooligosaccharidic Nod factors in legumes. Trends Plant Sci. 6:2430.

Dean, C., and Schmidt, R. 1995. Plant genome: A current molecular description. Annu. Rev. Plant Physiol. Plant Mol. Biol. 46:395-418.

den Hartog, M., Musgrave, A., and Munnik, T. 2001. Nod factor-induced phosphatidic acid and diacylglycerol pyrophosphate formation: A role for phospholipase C and D in root hair deformation. Plant J. 25:55-65.

Dénarié, J., Debellé, F., and Promé, J. C. 1996. Rhizobium lipo-chitooligosaccharide nodulation factors: Signaling molecules mediating recognition and morphogenesis. Annu. Rev. Biochem. 65:503-535.

Endre, G., Kaló, P., Kevei, Z., Kiss, P., Mihacea, S., Szakal, B., Kereszt, A., and Kiss, G. B. 2002a. Genetic mapping of the non-nodulation phenotype of the mutant MN-1008 in tetraploid alfalfa (Medicago sativa). Mol. Genet. Genomics. 266:1012-1019.

Endre, G., Kereszt, A., Kevei, Z., Mihacea, S., Kaló, P., and Kiss, G. B. 2002 b. Cloning of a receptor kinase gene regulating symbiotic nodule development. Nature. 417:962-966.

Etzler, M. E., Kalsi, G., Ewing, N. N., Roberts, N. J., Day, R. B., and Murphy, J. B. 1999. A Nod factor binding lectin with apyrase activity from legume roots. Proc. Natl. Acad. Sci. U.S.A. 96:5856-5861.

Fransz, P. F., Stam, M., Montijn, B., Ten Hoopen, R., Wiegant, J., Kooter, J. M., Oud, O., and Nanninga, N. 1996a. Detection of single copy genes and chromosome rearrangements in Petunia hybrida by fluorescence in situ hybridization. Plant J. 9:767-774.

Fransz, P. F., Alonso-Blanco, C., Liharska, T. B., Peeters, A. J., Zabel, P., and de Jong, J. H. 1996b. High-resolution physical mapping in Arabidopsis thaliana and tomato by fluorescence in situ hybridization to extended DNA fibres. Plant J. 9:421-430.

Fransz, P. F., Armstrong, S., de Jong, J. H., Parnell, L. D., van Drunen, C., Dean, C., Zabel, P., Bisseling, T., and Jones, G. H. 2000. Integrated cytogenetic map of chromosome arm $4 \mathrm{~S}$ of A. thaliana: Structural organization of heterochromatic knob and centromere region. Cell. 100:367-376.

Ghérardi, M., Mangin, B., Goffinet, B., Bonnet, D., and Huguet, T. 1998. A method to measure genetic distance between allogamous populations of alfalfa (Medicago sativa) using RAPD molecular markers. Theor. Appl. Genet. 96:406-412.

Gressent, F., Drouillard, S., Mantegazza, N., Samain, E., Geremia, R. A., Canut, H., Niebel, A., Driguez, H., Ranjeva, R., Cullimore, J., and Bono, J. J. 1999. Ligand specificity of a high-affinity binding site for lipo-chitooligosaccharidic Nod factors in Medicago cell suspension cultures. Proc. Natl. Acad. Sci. U.S.A. 96:4704-4709.

Harper, L. C., and Cande, W. Z. 2000. Mapping a new frontier: Development of integrated cytogenetic maps in plants. Funct. Integr. Genomics 1:89-98.

Jackson, S. A., Wang, M. L., Goodman, H. M., and Jiang, J. 1998. Application of fiber-FISH in physical mapping of Arabidopsis thaliana. Genome. 41:566-572.

Journet, E. P., Pichon, M., Dedieu, A., De Billy, F., Truchet, G., and Barker, D. G. 1994. Rhizobium meliloti Nod factors elicit cell-specific transcription of the ENOD12 gene in transgenic alfalfa. Plant J. 6:241249.

Kalo, P., Endre, G., Zimanyi, L., Csanadi, G., and Kiss, G. B. 2000. Construction of an improved linkage map of diploid alfalfa (Medicago sativa). Theor. Appl. Genet. 100:641-657.

Kiss, G. B., Kalo, P., Kereszt, A., Mihacea, S., and Endre, G. 2000. Nitrogen Fixation: From Molecules to Crop Productivity. Kluwer Academic Publishers, Dordrecht, The Netherlands.

Kulikova, O., Gualtieri, G., Geurts, R., Kim, D. J., Cook, D., Huguet, T., de Jong, J. H., Fransz, P. F., and Bisseling, T. 2001. Integration of the FISH pachytene and genetic maps of Medicago truncatula. Plant J. 27:49-58.

Lander, E. S., Green, P., Abrahamson, J., Barlow, A., Daly, M. J., Lincoln, S. E., and Newburg, L. 1987. MAPMAKER: An interactive computer package for constructing primary genetic linkage maps of experimental and natural populations. Genomics. 1:174-181.

Long, S. R. 1996. Rhizobium symbiosis: Nod factors in perspective. Plant Cell 8:1885-1898.

Meksem, K., Ruben, E., Hyten, D., Triwitayakorn, K., and Lightfoot, D. A. 2001. Conversion of AFLP bands into high-throughput DNA markers. Mol. Genet. Genomics 265:207-214.

Michelmore, R. W., Paran, I., and Kesseli, R. V. 1991. Identification of markers linked to disease-resistance genes by bulked segregant analysis: A rapid method to detect markers in specific genomic regions by using segregating populations. Proc. Natl. Acad. Sci U.S.A. 88:9828-9832.

Moreau, P., Thoquet, P., Olivier, J., Laterrot, H., and Grimsley, N. 1998. Genetic mapping of $\mathrm{Ph}-2$, a single locus controlling partial resistance to Phytophthora infestans in tomato. Mol. Plant-Microbe Interact. 11:259-269.

Nam, Y. W., Penmetsa, R. V., Endre, G., Uribe, P., Kim, D., and Cook, D. R. 1999. Construction of a bacterial artificial chromosome library of Medicago truncatula and identification of clones containing ethyleneresponse genes. Theor. Appl. Genet. 98:638-646.

Penmetsa, R. V., and Cook, D. R. 1997. A legume ethylene-insensitive mutant hyperinfected by its rhizobial symbiont. Science. 275:527-530.

Penmetsa, R. V., and Cook, D. R. 2000. Production and characterization of diverse developmental mutants of Medicago truncatula. Plant Physiol. 123:1387-1398.

Peterson, M. A., and Barnes, D. K. 1981. Inheritance of ineffective nodulation and non-nodulation traits in alfalfa. Crop Science. 21:611-616.

Pingret, J. L., Journet, E. P., and Barker, G. D. 1998. Rhizobium Nod factor signaling: Evidence for a $\mathrm{G}$ protein-mediated transduction mechanism. Plant Cell. 10:659-671.

Postma, J. G., Jacobsen, E., and Feenstra, W. J. 1988. Three pea mutants with an altered nodulation studied by genetic analysis and grafting. Plant Physiol. 132:424-430.

Sagan, M., de Larambergue, H., and Morandi, D. 1998. Biological Nitrogen Fixation for the 21st Century. Kluwer Academic Publishers, Dordrecht, The Netherlands.

Sagan, M., Morandi, D., Tarenghi, E., and Duc, G. 1995. Selection of nodulation and mycorrhizal mutants in the model plant Medicago truncatula (Gaertn) after gamma-ray mutagenesis. Plant Sci. 111:63-71.

Sambrook, J., Fritsch, E. F., Maniatis, T., and Irwin, N. 1989. Molecular Cloning: A Laboratory Manual. Cold Spring Harbor Laboratory, Cold Spring Harbor, NY, U.S.A.

Schneider, A., Walker, S. A., Sagan, M., Duc, G., Ellis, T. H. N., and Downie, J. A. 2002. Mapping of the nodulation loci sym 9 and sym10 of pea (Pisum sativum L.). Theor. Appl. Genet. 104:1312-1316.

Schultze, M., and Kondorosi, A. 1998. Regulation of symbiotic root nodule development. Annu. Rev. Genet. 32:33-57.

Spaink, H. P. Plant-microbe interactions: A receptor in symbiotic dialogue. Nature. 417:910-911. 2002.

Stracke, S., Kitsner, C., Yoshida, S., Mulder, L., Sato, S., Kaneko, T., Tabata, S., Sandal, N., Stougaard, J., Szczyglowski, K., and Parninske, M. 2002. A plant receptor-like kinase required for both bacterial and fungal symbiosis. Nature. 417:959-962.

Thoquet, P., Gherardi, M., Journet, E. P., Kereszt, A., Ané, J. M. Prosperi, J. M., and Huguet, T. 2002. The molecular genetic linkage map of the model legume Medicago truncatula: An essential tool for comparative legume genomics and the isolation of agronomically important genes. BMC Plant Biol. 2:1. Online publication.

Truchet, G., Debellé, F., Vasse, J., Terzaghi, B., Garnerone, A. M., Rosenberg, C., Batut, J., Maillet, F., and Dénarié, J. 1985. Identification of a Rhizobium meliloti pSym2011 region controlling the host specificity of root hair curling and nodulation. J. Bacteriol. 164:1200-1210.

Vos, P., Hogers, R., Bleeker, M., Reijans, M., van de Lee, T., Hornes, M., Frijters, A., Pot, J., Peleman, J., Kulper, M., and Zabeau, M. 1995. AFLP: A new technique for DNA fingerprinting. Nucl. Acids Res. 23:4407-4414

Wais, R. J., Galera, C., Oldroyd, G., Catoira, R., Penmetsa, R. V., Cook, D., Gough, C., Dénarié, J., and Long, S. R. 2000. Genetic analysis of calcium spiking responses in nodulation mutants of Medicago truncatula. Proc. Natl. Acad. Sci. U.S.A. 97:13407-13412.

Walker, S. A., Viprey, V., and Downie, J. A. 2000. Dissection of nodulation signaling using pea mutants defective for calcium spiking induced by Nod factors and chitin oligomers. Proc. Natl. Acad. Sci. U.S.A. 97:13413-13418.

Weeden, N. F., Kneen, B. E., and Larue, T. A. 1990. Nitrogen Fixation: Achievements and Objectives. Chapman and Hall, New York.

Zhong, X. B., Fransz, P. F., Wennekes-Eden, J., Zabel, P., Van Kammen, A., and de Jong, J. H. 1996. High resolution mapping by fluorescence in situ hybridization to pachytene chromosomes and extended DNA fibres. Plant Mol. Biol. Rep. 14:232-242.

Zhong, X. B., Bodeau, J., Fransz, P. F., Williamson, V. M., Van Kammen, A., de Jong, J. H., and Zabel, P. 1999. FISH to meiotic pachytene chromosomes of tomato locates the root-knot nematode resistance gene $\mathrm{Mi}-1$ and the acid phosphatase gene Aps-1 near the junction of euchromatin and pericentromeric heterochromatin of chromosome arms $6 \mathrm{~S}$ and 6L, respectively. Theor. Appl. Genet. 98:365-370.

\section{AUTHOR-RECOMMENDED INTERNET RESOURCES}

Software program from Colorado State University: http://www.colostate. edu/Depts/Biology/MicroMeasure 